\title{
HUBUNGAN KEPATUHAN TRANSFUSI DARAH TERHADAP PERTUMBUHAN ANAK THALASSEMIA DI RUMAH SINGGAH THALASSEMIA BANDAR LAMPUNG
}

\author{
Festy Ladyani Mustofa ${ }^{1}$, Nia Triswanti ${ }^{2}$, Prambudi Rukmono ${ }^{3}$ \\ Muhammad Furqan Satriadi ${ }^{4}$
}

\author{
${ }^{1}$ Departemen Gizi Medik Fakultas Kedokteran Universitas Malahayati \\ ${ }^{2}$ Departemen Biokimia Fakultas Kedokteran Universitas Malahayati \\ ${ }^{3}$ Departemen Perinatologi Rumah Sakit Abdul Moeloek Bandar Lampung \\ ${ }^{4}$ Program Studi Kedokteran Fakultas Kedokteran Universitas Malahayati
}

[e-mail korespondensi: muhammadfurqansatriadi@gmail.com]

\begin{abstract}
The Relationship Of Blood Transfusion Compliance With Children Growth With Thalassemia In Salgah House Thalassemia Bandar Lampung. Thalassemia in Indonesia is included in a group of high-risk countries. Based on data from the Indonesian Thalassemia Foundation / Association of Parents of Indonesian Thalassemia Patients it is known that people with thalassemia in Indonesia experienced an increase from 4,896 people in 2012 to 20129,028 people with 2018 . This study aims to determine the relationship between adherence to blood transfusions with the growth of children with thalassemia in thalassemia shelter Bandar Lampung.This study uses correlation analytic method with cross sectional approach. Sampling was done by purposive sampling technique. The sample in this study was children with thalassemia beta major aged 5-10 years who were recorded in a thalassemia transit home in Bandar Lampung totaling 55 respondents. The results showed that $65.5 \%$ of respondents who had good blood transfusion adherence and who had good growth were $76.4 \%$ of respondents. The results of the Spearman test, found that there is a significant relationship between adherence to blood transfusion on the growth of children with thalassemia $(p=0.019)$ : There is a significant relationship between the relationship of blood transfusion adherence to the growth of children with thalassemia. With a correlation coefficient value of 0.316 is positive which means the value of high blood transfusion adherence, the growth value of thalassemia children is also high, and vice versa if compliance with blood transfusion is low, the growth value of thalassemia children is also low.
\end{abstract}

Keywords: Compliance with blood transfusion, Thalassemia, Growth

\begin{abstract}
Abstrak: Hubungan Kepatuhan Transfusi Darah Terhadap Pertumbuhan Anak Dengan Thalassemia Di Rumah Singgah Thalassemia Bandar Lampung. Penyakit Thalassemia di Indonesia termasuk dalam kelompok negara yang berisiko tinggi. Berdasarkan data Yayasan Thalassemia Indonesia/Perhimpunan Orang Tua Penderita Thalassemia Indonesia diketahui bahwa penyandang thalassemia di Indonesia mengalami peningkatan dari 4.896 penyandang di tahun 2012 menjadi 9.028 penyandang pada tahun 2018 Penelitian ini bertujuan untuk mengetahui hubungan antara kepatuhan transfusi darah terhadap pertumbuhan anak dengan thalassemia di rumah singgah thalassemia Bandar Lampung. Penelitian ini menggunakan metode analitik korelasi dengan pendekatan cross sectional. Pengambilan sampel dilakukan dengan teknik purposive sampling. Sampel dalam penelitian ini adalah anak dengan thalassemia beta major yang berusia 5-10 tahun yang terdata di rumah singgah thalassemia Bandar Lampung berjumlah 55 responden. Hasil penelitian didapatkan $65.5 \%$ responden yang memiliki kepatuhan transfusi darah baik dan yang memiliki pertumbuhan baik sebanyak $76.4 \%$ responden. Hasil dari uji Spearman, didapatkan bahwa ada hubungan yang signifikan antara kepatuhan transfusi darah terhadap pertumbuhan anak dengan thalassemia $(p=0.019)$. Terdapat hubungan yang bermakna antara hubungan kepatuhan transfusi darah terhadap pertumbuhan anak dengan thalassemia. Dengan nilai koefisian korelasi 0.316 bertanda positif yang artinya nilai kepatuhan transfusi darah tinggi maka nilai pertumbuhan anak thalassemia juga tinggi, demikian sebaliknya bila kepatuhan transfusi darah rendah maka nilai pertumbuhan anak thalassemia juga rendah.
\end{abstract}


Kata Kunci : Kepatuhan transfusi darah, Thalassemia, Pertumbuhan

\section{PENDAHULUAN}

Thalasemia berasal daris kata Yunani thalassa (Laut) dan haema yang berarti darah penyakit ini pertama kali ditemukan pada orang-orang yang berasal dari Mediterania. Thalasemia merupakan gangguan sintesis hemoglobin yang bersifat herediter. Penyakit genetik yang memiliki jenis dan frekuensi terbanyak di dunia. Gejala yang ditimbulkan bervariasi mulai dari asimtomatik hingga gejala yang berat (Kemenkes RI, 2018). Penyakit ini ditandai dengan kondisi sel darah merah (eritrosit) yang umurnya pendek dari sel darah normal, yaitu 120 hari. Penyakit ini diturunkan dari orang tua kepada anaknya sejak masih dalam kandungan (Sukri, 2016).

Untuk prevalensi thalassemia itu sendiri menurut thallassemias International Federation Penyakit Thalassemia di Indonesia termasuk dalam kelompok negara yang berisiko tinggi. Salah satu penyakit genetik yang tersering di dunia adalah penyakit thalasemia. Kelainan genetik ini dikarenakan sumsum tulang tidak dapat membentuk protein untuk memproduksi hemoglobin (Potts \& Mandleco, 2007).

Badan kesehatan dunia atau WHO tahun 2020 menyatakan penduduk dunia mempunyai gen thalasemia kurang lebih $7 \%$ dan kejadian tertinggi mencapai $40 \%$ terdapat di negara-negara Asia. Indonesia sendiri prevalensi karier thalasemia mencapai 3-8\%. Pada tahun 2009, di Indonesia terjadi peningkatan sebesar $8,3 \%$ dari 3653 kasus thalassemia yang tercatat di tahun 2006 (Wahyuni, 2009).

Berdasarkan data Yayasan Thalassemia Indonesia/Perhimpunan Orang Tua Penderita Thalassemia Indonesia diketahui bahwa penyandang thalassemia di Indonesia mengalami peningkatan dari 4.896 penyandang di tahun 2012 menjadi 9.028 penyandang pada tahun 2018. Hingga saat ini pengobatan untuk thalassemia belum di temukan, akan tetapi penderita thalassemia dapat melakukan terapi yaitu transfusi darah secara rutin (Kemenkes RI, 2018).

Tujuan transfusi darah untuk mempertahankan kadar hemoglobolin
9-10 g/dl. Pembentukan sel darah merah yang mengalami kelainan sehingga sel darah merah umurnya tidak normal dan menyebabkan penurunan kadar hemoglobulin. Dalam melakukan transfusi darah penderita thalassemia harus secara rutin melakukannya agar tidak mengalami anemia yang berat (Febrianis, 2009).

Menurut penelitian Rosnia Safitri tahun 2015 pemberian transfusi darah yang patuh dan tidak patuh memiliki perbedaan presentasi, yaitu yang patuh melakukan transfusi darah memiliki pertumbuhan yang baik di bandingkan yang tidak patuh melakukan transfusi darah (Safitri, 2015). Dalam penelitiannya Wahidayat tahun 2006 menemukan bahwa $2,7 \%$ penderita thalassemia digolongkan ke dalam gizi baik, 64,1\% digolongkan ke dalam gizi kurang dan $13,2 \%$ digolongkan ke dalam gizi buruk (Wahidayat, 2006).

\section{METODE}

Penelitian ini menggunakan metode analitik korelasi dengan pendekatan cross sectional. Pengambilan sampel dilakukan dengan teknik purposive sampling. Sampel dalam penelitian ini adalah anak thalassemia beta major berusia 5-10 tahun di rumah singgah thalassemia Bandar Lampung, berjumlah 55 responden.

\section{HASIL}

Penelitian ini dilakukan pada pasien anak thalassemia beta major di rumah singgah thalassemia Bandar Lampung pada bulan Desember tahun 2019. Data penelitian yang digunakan adalah data primer diambil dengan memperhatikan kriteria inklusi dan kriteria eksklusi, didapatkan jumlah sampel sebanyak 55 sampel. Hasil penelitian dapat dilihat pada tabel dibawah ini.

\section{Karakteristik Responden}

Responden dalam penelitian ini adalah anak thalassemia beta major di rumah singgah thalassemia Lampung. Jumlah sampel dalam penelitian ini yaitu sebanyak 55 sampel. Adapun karakteristik responden adalah sebagai berikut: 
Tabel 1. Karakteristik Responden

\begin{tabular}{cccc}
\hline Variabel & Kategori & Frekuensi & Persentase \\
\hline Umur & 5 tahun & 4 & $7,3 \%$ \\
& 6 tahun & 11 & $20 \%$ \\
7 tahun & 16 & $29,1 \%$ \\
8 tahun & 14 & $25,5 \%$ \\
& 9 tahun & 10 & $18,2 \%$ \\
\hline Jenis Kelamin & Laki-laki & 31 & $56,4 \%$ \\
& Perempuan & 24 & $43,6 \%$ \\
\hline
\end{tabular}

Berdasarkan tabel 1 diatas dapat dilihat bahwa mayoritas umur anak dengan thalassemia beta major umur 7 tahun sebanyak 16 orang $(29,1 \%)$ dan mayoritas jenis kelamin anak dengan thalassemia beta major berjenis kelamin laki-laki sebanyak 31 orang $(56,4 \%)$.

\section{Analisa Univariat}

Analisa ini dilakukan untuk mengetahui distribusi frekuensi dan persentase dari variabel kepatuhan transfusi darah dan pertumbuhan anak thalassemia di rumah singgah thalassemia Bandar Lampung.

\section{Tabel 2. Distribusi Frekuensi} Kepatuhan Transfusi Darah

\begin{tabular}{lcc}
\hline $\begin{array}{c}\text { Kepatuhan } \\
\text { Transfusi } \\
\text { Darah }\end{array}$ & Jumlah & Presentase \\
\hline Patuh & 36 & $65,5 \%$ \\
Tidak Patuh & 19 & $34,5 \%$ \\
Jumlah & 55 & $100 \%$ \\
\hline \multicolumn{2}{c}{ Berdasarkan tabel 2 diatas } \\
$\begin{array}{l}\text { menunjukkan bahwa } \\
\text { kepatuhan }\end{array}$ \\
transfusi darah yang patuh melakukan \\
transfusi darah sebanyak 36 orang \\
dengan presentase $65,5 \%$ kemudian \\
yang tidak patuh melakukan transfusi
\end{tabular}

darah sebanyak 19 orang dengan presentase $34,5 \%$.

\section{Tabel 3. Distribusi Frekuensi} Pertumbuhan

\begin{tabular}{lcc}
\hline Pertumbuhan & Jumlah & Presentase \\
\hline Normal & 42 & $76,4 \%$ \\
Kurus & 13 & $23,6 \%$ \\
Jumlah & 55 & $100 \%$ \\
\hline
\end{tabular}

Berdasarkan tabel 3 diatas menunjukkan bahwa frekuensi pertumbuhan anak thalassemia yang dikategorikan pertumbuhan normal sebanyak 42 orang dengan presentase $76,4 \%$ kemudian yang dikategorikan pertumbuhan kurus sebanyak 13 orang dengan presentase $23,6 \%$.

\section{Analisa Bivariat}

Analisa ini dilakukan untuk mengetahui tingkat ketepatan hubungan variabel independent dengan variabel dependent yang diteliti yaitu hubungan Kepatuhan transfusi darah terhadap pertumbuhan anak dengan thalassemia di rumah singgah thalassemia Bandar Lampung 2019 sehingga diketahui kemaknaannya dengan menggunakan uji Spearman.

Tabel 4. Analisa Hubungan Kepatuhan Transfusi Darah Terhadap Pertumbuhan Anak Dengan Thalassemia

\begin{tabular}{|c|c|c|c|c|c|c|}
\hline \multirow{3}{*}{$\begin{array}{c}\text { Kepatuhan } \\
\text { Transfusi Darah }\end{array}$} & \multicolumn{4}{|c|}{ Pertumbuhan } & \multirow{3}{*}{ Total } & \multirow{3}{*}{$\%$} \\
\hline & \multicolumn{2}{|c|}{ Normal } & \multicolumn{2}{|c|}{ Kurus } & & \\
\hline & $\mathbf{N}$ & $\%$ & $\mathbf{N}$ & $\%$ & & \\
\hline Patuh & 31 & $56,36 \%$ & 5 & $9,09 \%$ & 36 & $64,45 \%$ \\
\hline Tidak Patuh & 11 & $20 \%$ & 8 & $14,55 \%$ & 19 & $25,55 \%$ \\
\hline Total & 42 & $76,36 \%$ & 13 & $23,64 \%$ & 55 & $100 \%$ \\
\hline
\end{tabular}

Berdasarkan hasil penelitian tabel 4 diperoleh hasil analisa hubungan antara kepatuhan transfusi darah terhadap pertumbuhan anak dengan thalassemia di rumah singgah thalassemia Bandar Lampung tahun 2019 bahwa dari 55 anak yang berusia 5-10 tahun terdapat 31 orang $(56,36 \%)$ 
yang patuh melakukan transfusi darah dengan status pertumbuhan normal $(-2$ SD sampai 1 SD) dan 5 orang $(9,09 \%)$ yang patuh melakukan transfusi darah dengan status pertumbuhan kurus ( -3 SD sampai <-2 SD) sedangkan 11 orang $(20 \%)$ yang tidak patuh melakukan transfusi darah dengan status pertumbuhan normal (-2 SD sampai 1 SD) dan 8 orang yang tidak patuh melakukan transfusi darah dengan status kurus (-3 SD sampai <-2 SD).

\section{Tabel 5. Tabulasi Silang Kepatuhan Transfusi Darah terhadap Pertumbuhan Anak dengan Thalassemia}

\begin{tabular}{cccc}
\hline Spearman & $\mathbf{N}$ & $\begin{array}{c}\text { Signifikan } \\
(\mathbf{p})\end{array}$ & $\begin{array}{c}\text { Correlation } \\
\text { Coefficient }\end{array}$ \\
\hline $\begin{array}{c}\text { Kepatuhan Transfusi Darah } \\
\text { Pertumbuhan Anak } \\
\text { Thalassemia }\end{array}$ & 55 & 0,019 & 0,316 \\
\hline
\end{tabular}

Berdasarkan uji statistik diperoleh nilai $p=0,019(p<0,05)$ maka dapat disimpulkan bahwa terdapat hubungan yang bermakna antara kepatuhan transfusi darah terhadap pertumbuhan anak dengan thalassemia di rumah singgah thalassemia Bandar Lampung tahun 2019. Berdasarkan hasil uji statistik juga didapatkan angka koefisien korelasi sebesar 0,316 yang berarti tingkat kekuatan hubungan (korelasi) antara variabel kepatuhan transfusi darah terhadap pertumbuhan anak dengan thalassemia adalah hubungan cukup kuat yang dimana nilai hubungan kekuatan cukup sebesar 0,26 sampai 0,50 .

\section{PEMBAHASAN}

Transfusi darah harus selalu dilakukan agar anak dengan thalassemia dapat mempertahankan kadar hemoglobin 9-10g/dl. Darah berperan penting dalam melakukan fungsi sistemik di dalam tubuh yaitu sebagai alat transportasi yang banyak mengandung komponen penting di dalamnya. Pasien thalassemia Beta major, tidak dapat memproduksi hemoglobin dengan bentuk yang normal, sehingga dapat mengganggu fungsi transportasi komponen-komponen yang dibutuhkan oleh organ tubuh yang mana organ tubuh melakukan fungsi pertumbuhan dan perkembangan (Safitri, 2015).

Faktor yang berperan pada pertumbuhan pasien thalasemia adalah faktor genetik dan lingkungan. Selain itu hemoglobin juga berpengaruh, bila kadar hemoglobin dipertahankan tinggi, lebih kurang $10 \mathrm{~g} / \mathrm{dl}$ disertai pencegahan hemokromatosis, maka gangguan pertumbuhan tidak terjadi (Kiswari, 2014). Gangguan pertumbuhan pada penderita thalasemia disebabkan oleh kondisi anemia dan masalah endokrin. Kondisi anemia dan masalah endokrin ini dapat mengganggu proses pertumbuhan anak penderita thalasemia, sehingga mengakibatkan gangguan pertumbuhan seperti postur yang pendek (Safitri, 2015). Untuk memenuhi kebutuhan darah yang diperlukan oleh tubuh penderita thalassemia, penderita thalassemia harus menjalani transfusi darah sepanjang hidupnya, apabila transfusi darah tidak dilakukan atau terhenti tanpa anjuran dari dokter akan mengakibatkan keadaan lebih fatal bahkan kematian (Smeltzer \& Bare, 2002).

Responden mayoritas patuh menjalani tranfusi sebanyak 31 responden $(56,36 \%)$. Kepatuhan adalah sejauh mana perilaku pasien sesuai dengan ketentuan yang diberikan oleh profesional kesehatan. Penderita thalasemia harus menjalani transfusi darah secara teratur dan rutin untuk menjaga kesehatan dan stamina penderita thalasemia, sehingga penderita tetap bisa beraktivitas. Tranfusi akan memberikan energi baru kepada penderita karena darah dari transfusi mempunyai kadar hemoglobin normal yang mampu memenuhi kebutuhan tubuh penderita. Penderita thalasemia membutuhkan transfusi darah karena hemoglobin penderita thalasemia tidak 
cukup memproduksi protein a atau $\beta$ sehingga mengakibatkan hemoglobin yang dibentuk menjadi berkurang dan sel darah merah mudah rusak (Dewi, 2009).

Penjabaran di atas telah menggambarkan tentang kepatuhan tranfusi darah, maka peneliti berasumsi bahwa kepatuhan pasien menjalani tranfusi darah berarti bahwa pasien beserta keluarga harus meluangkan waktu untuk menjalankan pengobatan yang dibutuhkan termasuk dalam menjalani tranfusi darah secara rutin.

Pada penelitian ini peneliti menemukan bahwa pada saat kunjungan ke rumah singgah thalassemia pasien thalassemia dapat melakukan transfusi darah dalam sebulan yaitu $2 x$ transfusi darah dan satu kali transfusi darah bisa 2 kantong darah yang di transfusikan yang mana satu kantong darah berisi 250cc darah. Apabila pasien thalassemia berat badannya kurang dari $45 \mathrm{~kg}$ untuk transfusi darahnya dilakukan satu hari satu kantong darah yang di transfusikan ke pasien thalassemia jika pasien thalassemia tersebut rawat jalan dan apabila pasien thalassemia yang berat badannya kurang dari $45 \mathrm{~kg}$ dapat melakukan transfusi darah satu kantong darah per 12 jam jika pasien thalassemia rawat inap.

Penelitian ini menemukan bahwa pertumbuhan normal pada anak thalasemia tergantung pada kepatuhan responden melakukan tranfusi darah secara teratur. Responden yang patuh menjalani tranfusi darah secara teratur dapat mempertahankan kadar hemoglobin $\mathrm{di}$ atas $7 \mathrm{~g} / \mathrm{dl}$. Kadar hemoglobin yang dipertahankan di atas 7 $\mathrm{g} / \mathrm{dl}$ dapat mempengaruhi pertumbuhan pasien thalassemia.

Pada penelitian ini berdasarkan uji statistik diperoleh nilai $p=0,019$ $(\mathrm{p}<05)$ maka dapat disimpulkan bahwa terdapat hubungan yang bermakna antara kepatuhan transfusi darah terhadap pertumbuhan anak dengan thalassemia di rumah singgah thalassemia Bandar Lampung tahun 2019. Penelitian ini sejalan dengan penelitian sebelumnya yang di lakukan oleh Rosnia yang mengatakan ada hubungan yang bermakna antara kepatuhan transfusi darah dan konsumsi kelasi besi terhadap pertumbuhan anak dengan thalassemia dengan nilai $\mathrm{p}=$ $0,038(p<0,05)$ (Safitri, 2015).
Hasil penelitian ini sesuai dengan penelitian yang dilakukan Asadi-Pooya, Karimi, dan Immanieh tahun 2004 menunjukkan adanya hubungan antara kadar hemoglobin ratarata sebelum transfusi dan kecepatan pertumbuhan. Penelitian tersebut memperlihatkan bahwa semakin rendah kadar hemoglobin rata-rata sebelum transfusi maka kecepatan pertumbuhan semakin berkurang. Hal ini dikarenakan pasien thalasemia tidak patuh menjalani tranfusi, sehingga pertumbuhannya terganggu (Asadi-pooya, 2004).

Penelitian yang dilakukan Saxena tahun 2015 juga memperlihatkan bahwa pasien dengan kadar hemoglobin rata-rata yang rendah sebelum transfusi $(<7,4 \mathrm{~g} / \mathrm{dL})$ dapat mengalami gangguan kecepatan pertumbuhan. Hasil penelitian di atas menunjukkan bahwa tranfusi darah dapat mencegah gangguan pertumbuhan pada anak dengan thalasemia. Faktor yang dianggap berperan terhadap kecepatan pertumbuhan anak dengan thalassemia adalah tinggi badan pada saat pertama kali pengukuran, penggunaan zat pengikat besi, volume darah rata-rata yang diterima saaat dilakukan tranfusi, dan keteraturan tranfusi (Saxena, 2015). Penelitian ini tidak sejalan dengan penelitian yang dilakukan oleh Frederica tahun 2017 tentang hubungan jumlah transfusi terhadap kadar hormon TSH (hormon pertumbuhan) yang menyatakan hubungan yang tidak bermakna antara hubungan jumlah transfusi darah terhadap kadar hormon TSH dengan $p=0,851$ yang mana TSH merupakan hormone pertumbuhan. Hasil penelitian menunjukkan 10 subjek $(25 \%)$ yang mengalami kenaikan kadar $\mathrm{TSH}$, sedangkan 30 subjek lainnya (75\%) memiliki kadar TSH yang normal. Hal ini berarti sebanyak 10 subjek dicurigai menderita hipotiroid. Hipotiroid ini mungkin dapat berhubungan dengan akumulasi zat besi pada kelenjar tiroid yang disebabkan oleh transfusi rutin dan berulang. Terdapat beberapa kemungkinan penyebab kadar TSH (hormon pertumbuhan) tidak meningkat pada pasien thalassemia yang rutin menerima transfusi. Kemungkinan yang pertama adalah penggunaan terapi kelasi yang rutin (Frederica, 2017). 


\section{KESIMPULAN}

Berdasarkan hasil penelitian hubungan kepatuhan transfusi darah terhadap pertumbuhan anak dengan thalassemia di rumah singgah thalassemia Bandar Lampung tahun 2019, maka dapat disimpulkan:

1. Diketahui karakteristik pasien Anak dengan Thalassemia di rumah singgah thalassemia Bandar Lampung tahun 2019 yaitu distribusi frekuensi kepatuhan transfusi darah didapatkan yang patuh melakukan transfusi darah sebanyak 36 orang $(65,5 \%)$ dan distribusi pertumbuhan anak thalassemia didapatkan yang normal (-2 SD sampai 1 SD) sebanyak 42 orang $(76,4 \%)$.

2. Diketahui terdapat hubungan yang bermakna antara kepatuhan transfusi darah terhadap pertumbuhan anak dengan thalassemia di rumah singgah thalassemia Bandar Lampung yang berarti kepatuhan transfusi darah tinggi maka nilai pertumbuhan anak thalassemia juga tinggi, demikian sebaliknya bila kepatuhan transfusi darah rendah maka nilai pertumbuhan anak thalassemia juga rendah.

\section{SARAN}

Hasil penelitian ini dapat digunakan sebagai evidence based dan sumber informasi tentang kepatuhan tranfusi terhadap pertumbuhan anak dengan thalasemia, dapat menjadi acuan masyarakat khususnya orang tua anak penderita thalasemia agar menjaga kondisi kesehatan anaknya, dan patuh menjalani tranfusi darah secara teratur agar pertumbuhan anaknya dapat normal seperti anak-anak lainnya, diharapkan petugas kesehatan dapat memberikan asuhan keperawatan dan health education kepada pasien karena thalasemia merupakan penyakit herediter yang kemungkinan besar dapat mengalami gangguan berbagai aspek yang dapat mempengaruhi pertumbuhan anak dengan thalasemia, dan penelitian ini dapat dijadikan sebagai evidence based dan tambahan informasi untuk mengembangkan penelitian lebih lanjut mengenai faktor-faktor yang mempengaruhi pertumbuhan anak dengan thalasemia selain dari kepatuhan tranfusi darah.

\section{DAFTAR PUSTAKA}

Asadi-Pooya, A, A., Karimi, M., \& Immanieh, M, H. (2004). Growth retardation in children with beta thalassemia major. Haematolgy

Dewi, S. (2009). Karakteristik penderita thalasemia yang rawat inap di Rumah Sakit Umum Pusat Adam Malik Medan. Diperoleh tanggal 5 Januari 2015 dari http://repository.usu.ac.id

Frederica, H., Meita, H. (2017). Hubungan Jumlah Transfusi Dengan Kadar Tsh Pada Thalassemia. JKD. Diponerogo

Febrianis, S. (2009). Gambaran tumbuh kembang pada anak dengan thalasemia. Pekanbaru

Hamizah, L., Susanah, S., \& Rakhmilla, L. E. (2017). Clinical Manifestations of Children With Thalassemia Major: Clinical Course One Year Later. Asian Journal Of Biological And Medical Sciences, III

Kemenkes RI. (2018). Thalasaemia Bukan penyakit Menular. Jakarta : Pusat Komunikasi Publik Sekjen Kemenkes RI.

Kemenkes RI. (2018). Keputusan Menteri Kesehatan Republik Indonesia Tentang Pedoman Nasional Pelayanan Kedokteran Tatalaksana Thalassemia

Kiswari, R. (2014). Hematologi dan Transfusi. Jawa tengah: Erlangga

Potts, N. L. \& Mandleco, B. L. (2007). Pediatric nursing.Caring for children \& their families ( 2 nd ed). New York: Thomson Coorporation

Safitri, R., Ernawati, J., \& Karim, D. (2015). hubungan kepatuhan tranfusi dan konsumsi kelasi besi terhadap pertumbuhan anak dengan thalassemia. Riau: Universitas Riau

Saxena, A. (2015). Growth Retardation in Thalassemia Major Patient. Int J Hum Genet.

Smeltzer \& Bare. (2002). Buku ajar Medikal Bedah Brunner \& Suddart (alih Bahasa Agung Waluyo) Edisi 8 Vol.3. Jakarta : EGC

Sukri, A. (2016). talasemia: Mengenal, Mendampingi dan Merawat. Jakarta: Bee Media Pustaka.

Walida, F. (2018). hubungan frekuensi transfusi darah dan derajat depresi pada anak talasemia mayor di rsud dr.m. yunus Bengkulu. 
Wahidiyat, P., \& Adnani, N. (2006). Transfusi Rasional Pada Anak. Sari Pediatri, 325-31. (bab 2)

Wahyuni, S. (2009). Perb\&ingan kualitas hidup anak penderita thalasemia dengan saudara penderita thalasemia yang normal.Diperoleh pada tanggal 15 Agustus 2019 dari repository.usu.ac.id/bitstream/123 456789/.../Appendix.pdf. 